\title{
Deposit insurance systems of post-Soviet countries: A comparative analysis
}

\author{
Andreas Horsch \\ Faculty of Economics, Technische Universität Bergakademie Freiberg \\ Germany \\ andreas.horsch@bwl.tu-freiberg.de \\ Larysa Sysoyeva \\ Department of Finance, Banking and Insurance, Institute for Business \\ Technologies ' $U A B$ ' of the Sumy State University \\ Ukraine \\ l.sysoieva@uabs.sumdu.edu.ua

\section{Sergii Bogma} \\ Assurance \& Advisory, Financial Services, PJSC Deloitte \& Touche \\ USC', Kiev \\ Ukraine \\ sbogma@deloitte.ua
}

\begin{abstract}
The article provides a comprehensive analysis of deposit insurance systems in the post-Soviet countries as of December 2017. The article brings up to date the earlier databases of Demirgüç-Kunt and various co-authors, covering 15 postSoviet countries exclusively. The analysis shows that post-Soviet countries are on their way developing deposit insurance systems that can effectively protect clients and help establish a stable financial system. Altogether, the most crucial factor which does not allow post-Soviet countries to fully accept the EU deposit insurance regulations is the divergent course of economic development. The findings are further illustrated along the particular case of Ukraine.
\end{abstract}

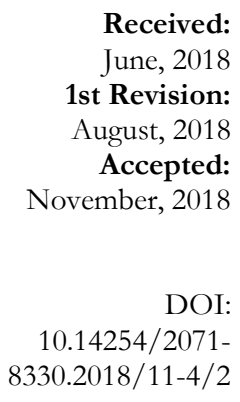

Keywords: post-Soviet countries, deposit insurance, banking systems, European integration.

JEL Classification: G21, G28, P20

\section{INTRODUCTION}

After the breaking up of the former Soviet Union, all of its successor countries faced the problem of establishing the institutional framework which is crucial for a viable financial system. Among the organizations to evolve were commercial banks offering savings and loans, leading directly to the problems of the legal status of banking deposits and their effective insurance in cases of bank insolvency. As other firms, banks are exposed to various types of risk. At the same time, particular creditors of banks, i.e. 
depositors, are regarded as protection-worthy. Their protection is also based on near-/non-economic considerations such as (in-)justice, but mainly built on the urgency to avoid depositors run on the bank, thus aggravating any crisis. Consequently, depositor protection schemes are designed to complement the preventive supervision of banks. Every nation which resulted from the splitting up of the Soviet Union had to decide on establishing a deposit insurance a) in general and b) in detail. Against this backdrop and frame of reference, this article takes stock and illustrates how the respective countries have dealt with these seminal questions by comparing their systems of deposit insurance.

While the second section of this article provides an introductory review of the existing literature, the thir done considers the existing deposit insurance systems in 15 post-Soviet countries, which share the same origin, but have been developing individually thereafter, and analyzes this particular and well-defined selection in a comparative manner. In general, we hypothesizethat in every of these countries a deposit insurance system was installed, in fact quickly and according to basic design principles. We first introduce the catalogue of criteria we have used for comparison based on seminal contributions that have been made - in particular, by Demirgüç-Kunt and various co-authors under the IMF/World Bank umbrella - to this field of research. Based hereupon, we present a detailed comparison of the deposit insurance schemes in the selected group of countries. The fourth section contributes to the analysis of deposit insurance experience in those of the aforementioned countries which have already joined the EU or are considered its associate members. In this part, the EU Directive on Deposit Guarantee Schemes and its amendments are regarded in brief, including a comparison of its requirements with the current systems in the countries analyzed. The fifth setion of the article evaluates the equivalence between the established EU regulation of deposit insurance and its application to current banking markets. Ukraine is chosen as a case study to evaluate the effectiveness of the existing deposit insurance system, because governing the functioning and effectiveness of the deposit insurance system, which plays a prominent role in the financial system, has been established as one of the priorities for assuring the development, stability and sustainability of Ukraine's economic system, which evolved considerably during the years of Ukraine's independence and also under the recent financial and political crises. In particular, the respective Ukrainian legislation of 2012 on responsibilities of the national Deposit Guarantee Fund and its amendments are considered. Although Ukraine has experienced several amendments to legislation on banking activity, banking regulation and deposit insurance during recent years, the aforementioned legislation does still represent the relevant legal foundation of Ukrainian deposit insurance (Alyeksyeyev \& Mazur, 2018). Section six concludes this article.

\section{LITERATURE REVIEW AND DERIVATION OF THESES}

The beginnings of bank deposit insurance can be traced back to the 19th century (Calomiris, 1990; Calomiris \& White, 1994; Golembe, 1960). Since then, deposit insurance has become part of an increasing number of financial systems worldwide. Although comparable protection schemes are possible for other types of financial intermediaries, e.g. insurance companies (seminal, see Cummins, 1988, and further of his contributions; also Lee, Mayers, \& Smith, 1997), theory and practice focus their role within banking systems (Demirgüç-Kunt \& Sobaci, 2001; Demirgüç-Kunt et al., 2005) and the problem of depositors` protection which is needed to withstand bank runs and consecutive bank failures. Developed countries were the first to introduce deposit insurance systems - and since then suggest their usefulness to developing countries (Demirgüç-Kunt \& Kane, 2002; Demirgüç-Kunt et al., 2015). While their mere existence is hardly discussed in practice anymore, economic analysis takes a more skeptical position towards deposit insurance, questioning its necessity and design based on the danger of distorted incentives: As any form of insurance, deposit insurance reduces the risk of the protected party to be harmed by a particular economic risk. And as any form of insurance, deposit insurance thus entails the problems of adverse selection and moral hazard 
(seminal, see Pauly, 1974; also Masciandaro, 2007). Being aware of their being covered by deposit insurance, bank depositors are less incentivized to screen and monitor their bank (managers and owners), who in turn are incentivized to gamble for high, but individualised profit, while at the same time socialising the inherent risk, although bankruptcy imposes significant monetary costs on the banks (seminal, Demirgüç-Kunt \& Detragiache, 2002; also Stiglitz, 1975; on the particular Russian experience, see Chernykh \& Cole, 2011; Fungáčová et al., 2017). To overcome this inbuilt flaw, different countries follow different institutional designs of deposit insurance. On a lower level, some deposit insurance schemes attempt to readjust incentives by being incentive compatible, e.g. by deductibles for customers, or risk-based insurance premiums for banks (e.g. Beck, 2003; Demirgüç-Kunt et al., 2008a; Hall, 2002; especially on risk-based premiums, see Chan et al., 1992). On a higher level, the interplay of deposit insurance and bank supervision has to be addressed: As banking regulation aims at system protection and depositor protection (extensively, see Benston, 1998), too, their combination seems only natural.

After their independence, the post-Soviet countries experienced particular institutional change (extensively, Schönfelder, 2012, chapters 1 - 8), including the development and revision of their deposit insurance mechanisms. During the early years of independence, deposit insurance used to be implicit before it was turned into explicit forms, which were considered best practice in many countries around the world (Garcia, 1999). However, bank depositors in the successor countries suffered severe losses due to bank failures and inflation, while they were not covered by existing deposit insurance (see Niinimäki, 2002).

Investigating the causes of bank failures in post-Soviet countries, Palubinskas \& Stough (1999) identified that decentralization and transformation processes had led to bank failures that left private clients unprotected. Compared to the majority of developed countries, the crucial impulse to create a deposit insurance system thus was a seminal political turnaround, followed by crises of financial intermediaries. Due to the preceding political meltdown, the institutional framework had to be created out of nothing, while institutions of deposit insurance had been part of the longtime institutional change in most developed countries. From an economic point of view, (governmental) deposit insurance is considered a way of financial regulation that is particularly attractive for rule-makers and regulators alike, because immediate cost is low, while the immediate benefits for these actors are high (e.g. Demirgüç-Kunt \& Kane, 2002). Consequently, we hypothesize that deposit insurance schemes were introduced rather quickly after postSoviet countries gained their independence. With regard to a swift establishment of deposit insurance, we furthermore expect their design to be rather simple and close to Western European blueprints. Meanwhile, several post-Soviet countries have become associate or full members of the EU. This leads to the question in how far the national deposit insurance systems were influenced by EU standards recently, as the continuing institutional change was supposed to affect any EU member state: While concentrating on bank supervision and insolvency avoidance since the 1990s, EU financial regulation put more emphasis on deposit insurance and insolvency management recently. Referring to the individual approaches of the member states, Gerhardt \& Lannoo (2011) show that EU deposit insurance should be improved by mitigating differences between national deposit insurance schemes. Recent EU legislation on deposit insurance in fact has been changing along with new challenges materializing in the wake of the financial crises (e.g. Laeven, 2014). In particular, the current Directive 2014/49/EU, which amends prior legislation (Directives 2009/14 EC and 94/19/EC, which explicitly made deposit protection an essential element of the completion of the internal market and of the instruments enforced for the sake of financial system stability) made the establishment of bank-financed guarantee funds compulsory, increased the minimum coverage amount from EUR 20,000 to EUR 100,000 per customer and bank, defined a minimum fund size (of $0.8 \%$ of protected deposits) and also shortened time limit for the funds' compensation payments in case of bankruptcy (e.g. Payne, 2015). This means that the new directive addressed all the main categories of deposit insurance design as they are discussed in the subsequent chapter. As of today, all current EU member 
states have implemented the main elements of a deposit insurance system according to the original directive and its recent amendments, although seminal questions still remain unanswered (e.g. Howarth \& Quaglia, 2017).

At the same time, the EU is considering supranational approaches towards deposit insurance. Schoenmaker \& Gros (2012) concluded that a European Deposit Insurance and Resolution Authority should be established to stabilize the retail deposit base and resolve troubled cross-border banks. A European Deposit Insurance and Resolution Fund would be fed through regular risk-based deposit insurance premiums with a fiscal backstop of the European Stability Mechanism. At the same time, the most recent change about to take place in future years is the introduction of a European Deposit Insurance Scheme as the third pillar of the EU Banking Union in order to reduce the potential spill-over risk of local bank failures on the financial stability of the economic and monetary union as a whole (Stuchlik, 2016).

Based upon our literature review, we thus hypothesize that deposit insurance systems were established in any post-Soviet country in a quick manner, aiming at depositor protection and system stability (Arzhevitin, 2010; Dovgan, 2012; Kravchuk \& Vilkhovyk, 2014; Strassberger \& Sysoyeva, 2016). Following the findings of Demirgüç-Kunt \& Kane (2002, p. 178) that the 'design of deposit insurance schemes varies substantially across countries [and the] high degree of variation suggests that an optimal worldwide blueprint is not likely to be found', we further expect different institutional designs in detail, but compatibility with the blueprints codified in EU directives on deposit insurance.

\section{TAKING STOCK: DEPOSIT INSURANCE SYSTEMS OF POST-SOVIET- COUNTRIES}

\subsection{Evolution of the status quo}

In 1991, economic, political, and social structures of the Soviet Union started to dissolve, while 15 post-Soviet countries gained their independence and started their existing as separate communities, starting to evolve their own institutional framework, including a national financial system. The economy of the Soviet Union had experienced stagnation processes before the break-up. The centrally and government-led planned economy had become increasingly inefficient year by year, and recent reforms turned out unsuccessful. By the end of the 1980s, supply problems in consumer industries became as evident as a worsening of medical and educational services, significantly driving a downturn of macroeconomic indicators and growing dissatisfaction of the people, so that economic recession turned into the break-up of the political Union. Hereafter, the independent successor states started adopting political, social, economic reforms and implementing policies individually. The results of these measures were different among the countries, as shown by macroeconomic indicators, especially GDP. To compare the general economic development of the post-Soviet countries, and to eliminate the possible effects of changes in exchange rates of currencies we used GDP rate based on PPP (purchasing power parity) for the period 1991-2017.

Figure 1 shows the positive trend of the GDP of post-Soviet countries during the years of independence. To take into account the considerable differences of populations, subsequent Fig. 2 also shows the GDP per capita ratio (based on PPP) for the same research period.

Figure 2 shows top positions of the Baltic countries (Estonia, Lithuania and Latvia) by GDP per capita, being the countries with the close geographical and economical connections with the European Union. Belarus, Kazakhstan, Russian Federation and Turkmenistan form the next group of countries according to GDP per capita. As of 2017 , the bandwidth is considerable, ranging from Tajikistan (3,180 US\$) to Lithuania 
(32,092 US\$). Against this macroeconomic backdrop, the post-Soviet countries had to evolve their individual institutional framework.

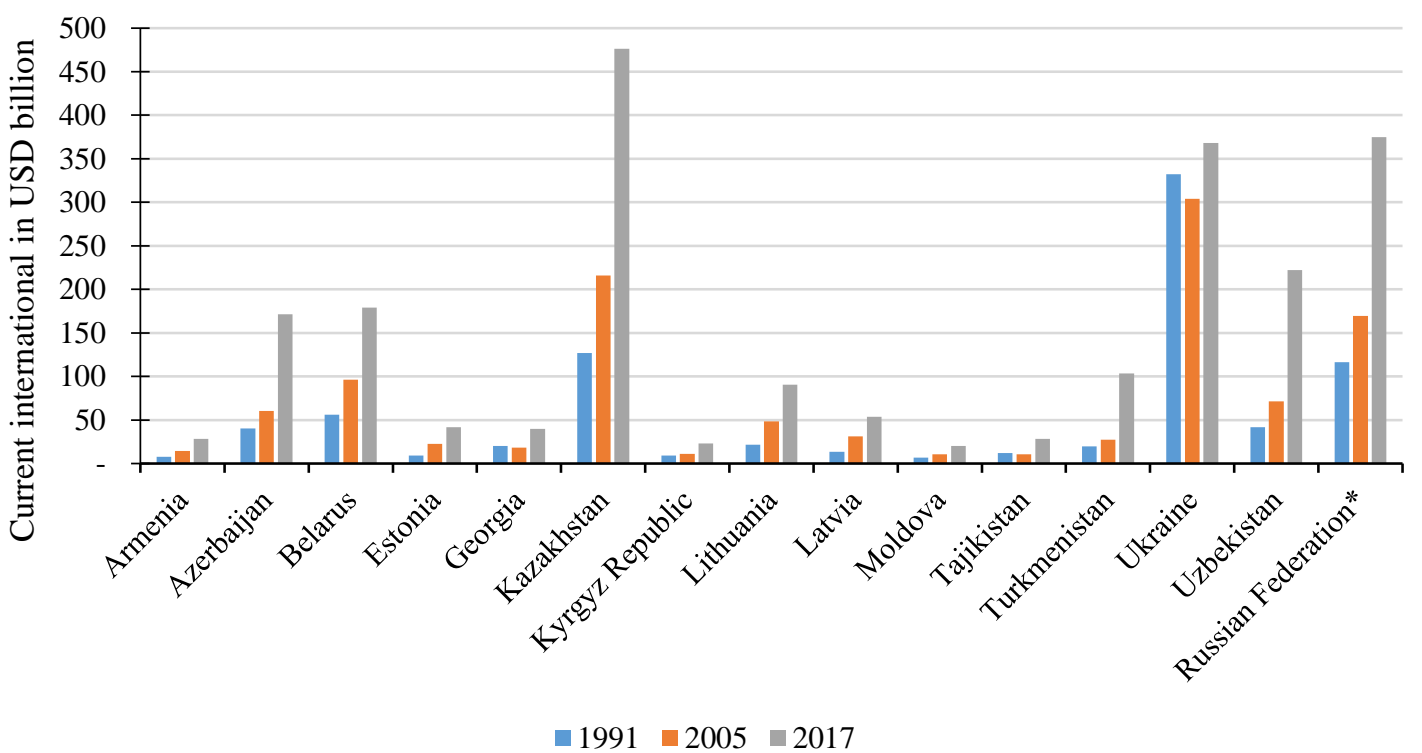

*Amounts for the Russian Federation estimated in USD 10 billion; first column for Baltic countries and Moldovia as of 1995

Figure 1. GDP PPP for post-Soviet countries (1991, 2005, 2017)

Source: World Bank Statistics (http://data.worldbank.org)

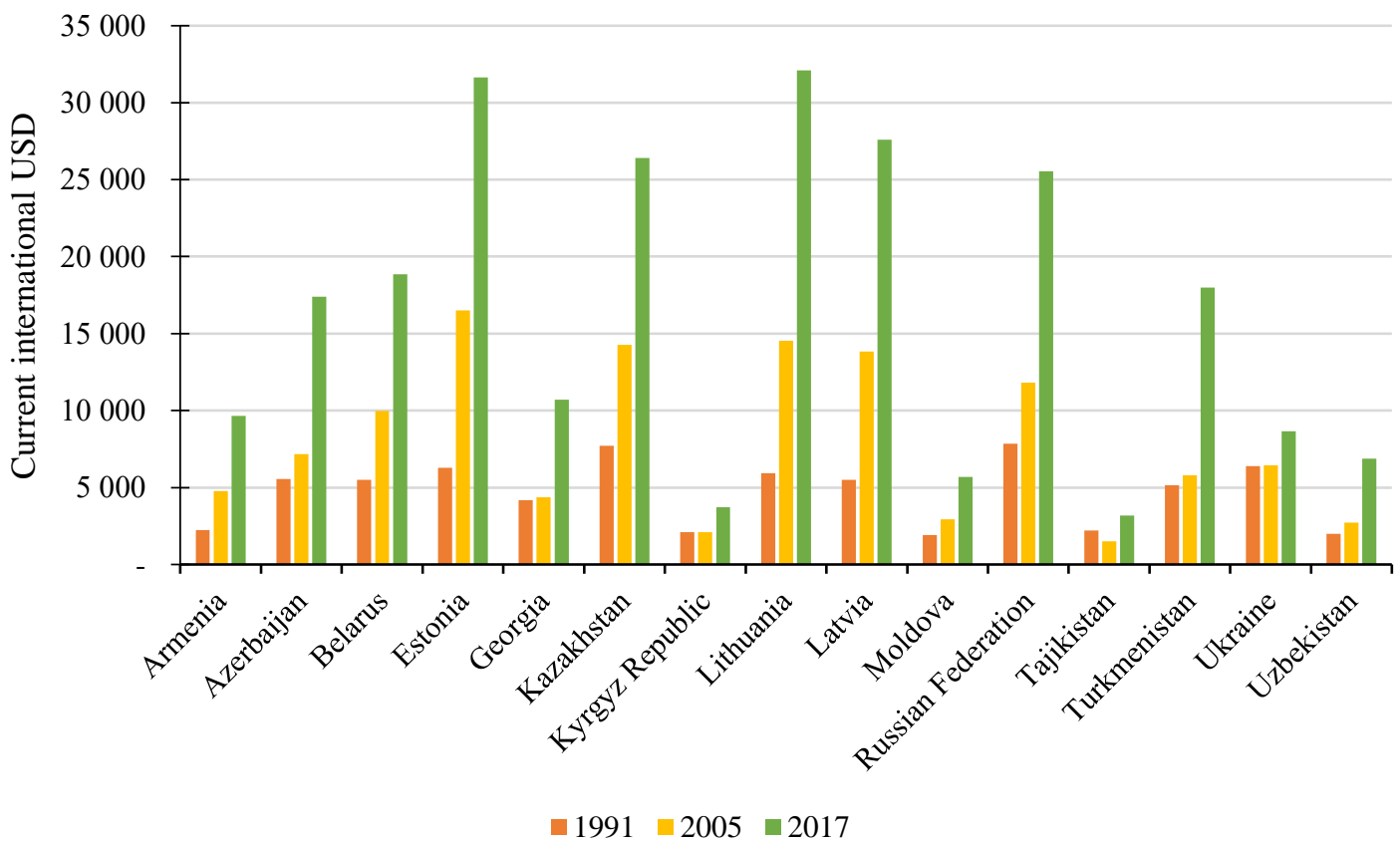

*First column for Baltic countries and Moldovia as of 1995

Figure 2. GDP per capita (PPP) for post-Soviet countries $(1991,2005,2017)$

Source: World Bank Statistics (http://data.worldbank.org) 
With the stepwise establishment of banking systems including privately owned (and thus exposed to insolvency risk) banking firms, the issue of depositor protection arose. Frequent crisis events in the 1990s (such as the economic crisis in Russia in 1998) endangered the evolution of sound banking systems in which clients could trust their banks, in particular when deposit insurance was not yet established (Savchenko \& Kovács, 2017; Cojocaru et al., 2016, 225; IADI, 2009). One of the traditional institutions to enhance depositor protection (and trust) is the protection of deposits by institutions explicitly designed for this purpose. Ukraine was one of the first successor countries to establish a respective deposit guarantee system for private bank depositors in 1998. Since then, the other successor countries followed suit, as the subsequent timeline of Fig. 3 shows.

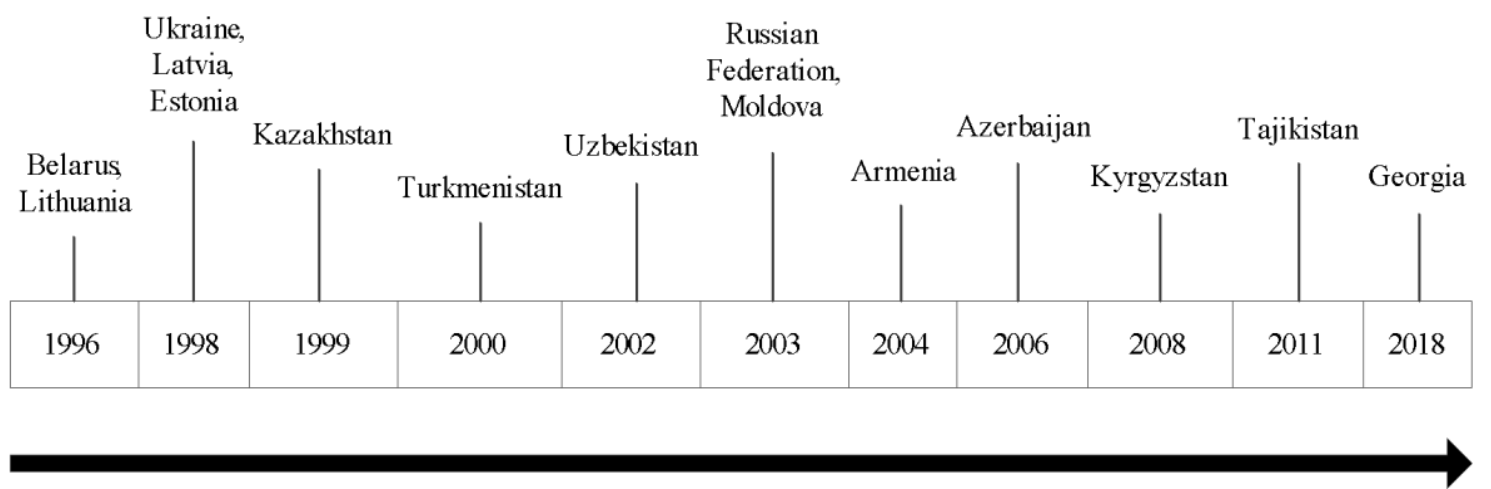

Figure 3. Evolving of initial deposit insurance institutions of post-Soviet countries Source: Authors' own compilation

Although deposit insurance institutions prevail in most of the aforementioned countries today, their designs still differ, meaning that the question of (the appropriateness of) bank depositors ` protection has remained one of the most urgent problems for the independent countries which succeeded the Soviet Union (where this topic had not been one at all), because their financial systems evolving turned out to be closer to the (continental) European, bank-/control-oriented prototype than to its market-oriented pendant (as e.g. in the US or the UK; on types of financial systems, see, extensively, Allen \& Gale, 2000) so that the banking sector is of seminal importance for ensuring the stability of the whole economic system of the country. Consequently, it becomes an urgent task to prevent banking panics and the subsequent massive withdrawal of household deposits.

Until today, the establishment of deposit insurance systems is still underway in most of the 15 countries. To understand the peculiarities of this slow process and its results, a comparative analysis promises further insights. For this purpose, we built up a database on deposit insurance for the aforementioned 15 postSoviet countries.

Scientific literature already offers comprehensive databases of deposit insurance systems, which were established by Demirgüç-Kunt and various co-authors under the IMF/World Bank umbrella: initiated by Demirgüç-Kunt \& Sobaci (2001) in 1999, and updated by Demirgüç-Kunt et al. (2005, also 2008b), and Demirgüç-Kunt et al. (2015). This IMF-database allows for extensive cross-country analyses of deposit insurance around the world and also takes into account amendments of the former systems which were spurred by the financial crisis since 2007.

With respect to the scope of our analysis, based on the variables used in this database of 2001, 2005 and 2015, we have chosen a set of those which are suitable to carry out a comparative analysis of deposit insurance schemes in post-Soviet countries. We extend this database by adding recent changes adjustments 
of the systems of several countries as of December 2017, including not only revisions of existing systems, but also initial adoptions of deposit insurance elements in some countries. Consequently, the analysis covers the time period of 1991-2017, the figures for coverage limit, payments, periods, etc. are presented as of December 2017.

In addition to information provided by the database of Demirgüç-Kunt et al. (2015), we extracted additional information from the websites of governmental and deposit insurance institutions of the countries analyzed. Further variables refer to the status of the countries' relation to the EU in particular. Table 1 shows a spreadsheet of our database that allows for a comparative analysis of the current landscape of post-Soviet deposit insurance schemes.

Prior to this synopsis, we describe the variables we used for comparison.

\subsection{Criteria to compare the current systems}

Systems of deposit insurance are specific organizations which are established according to specific rules. As an organization, they are characterized by three key features: coverage, funding, and managerial / organizational structures (Demirgüç-Kunt \& Kane, 2002, 182; Demirgüç-Kunt et al., 2015, 158, 162). According to the seminal contributions of Demirgüç-Kunt et al., these key features can be split up into subcategories - that allow for a more detailed description and comparison - as follows, whereas we add a fourth and meta-category that refers to the general purpose and specificity of deposit insurance.

1) General purpose and specificity

General purpose (and further functions): According to financial economics (see e.g. Diamond \& Dybvig, 1983, Goodman \& Shaffer, 1984), the main goal of deposit insurance of any country should be to provide protection for a) clients` deposits and b) the national financial system as a whole. Generally speaking, the goal of every deposit guarantee institution is to provide guarantees to depositors of financial institutions that their savings are safe, and that in the unlikely case of bank insolvency, they will ensure appropriate repayment of deposits. However, the formulations of the general goals of deposit insurance authorities differ according to the respective standards and their enforcement. Besides, there are further functions, mostly on an operational level, that can be taken into account, including the execution of (quasi)governmental powers. Taking part in banking regulation, the deposit insurance institution could be responsible in particular for: administering bank licences, closing down insolvent banks and organising their liquidation (e.g. Ukraine), supporting the sale of assets of banks which are in the procedure of liquidation (e.g. USA, Argentina, Germany, Poland), creating bridge banks (e.g. UK, Poland, USA).

Specificity: The presence of written law on deposit insurance is the main factor in defining its explicit or implicit form (Demirgüç-Kunt \& Sobaci, 2001; Demirgüç-Kunt et al., 2008a). The formal kind of regulation implies the presence of a particular deposit insurance legislation and regulation that is carried out by special authorities such as the national central bank, the banking supervisory authority, or a specialized deposit guarantee fund institution. In particular, the legislative basis and appropriate authorities of deposit guarantee regulation determine such important elements of deposit insurance as categories of insured depositors, coverage limits, triggers of repayment et al. We consider deposit insurance to be explicit if there are elements of a formal legislation or regulation outlining explicit deposit coverage, which are implemented in the country. Otherwise, we identify a deposit insurance system as an implicit one.

2) Coverage

The scope of coverage: In a qualitative sense, deposit insurance schemes differ with regard to the kinds of bank deposits they cover (e.g. Demirgüç-Kunt \& Detragiache, 2002). Relevant systematisations of bank liabilities can be tied to a) kinds of deposits (just principal, or interest, too; demand, time, saving, or other deposits; local vs. foreign deposits), b) the kind of depositor (private, entrepreneur, corporate, bank, public, 
or other), or c) the kind of the deposit-taking financial intermediary (commercial bank, building association, etc.). In a quantitative respect, deposit insurance schemes often name an upper limit of coverage (e.g. Demirgüç-Kunt et al., 2015). This cap can be an absolute number (denominated in currency units) or a percentage (of insured deposits, the bank's equity, or other volumes). Furthermore, it can be applied per depositor or per account. Any type of deductible emerging from these caps mitigates coverage, but also the moral hazard effects caused by the particular insurance type of deposit protection as well as by any other form of insurance.

Time of compensation: Deposit protection institutions are obliged to make compensation payments to depositors within the coverage limits only after a trigger incident occurred. The timeliness of the compensation, however, can vary, from being a particularly quick matter of days to requiring several years (e.g. Laeven, 2014). We distinguish the existence of emergency rules and also the procedures intended before a final compensation can take place, such as an announcement of the bank`s bankruptcy, registering of depositors involved, establishing partner institutions to organize pay-outs, etc., which can be rather timeconsuming.

3) Funding

Time refers to the distinction of unfunded and funded systems (e.g. Demirgüç-Kunt \& Huizinga, 2004). Unfunded systems do not collect contributions from member banks or third parties ex-ante, but just their formal obligation to contribute money at the very moment a bank insolvency occurs (e.g. Austria, Italy, or the UK, e.g. Laeven, 2014). Funded systems are based on ex-ante premia, which build up a reserve fund of financial resources that can be used for pay-outs to clients in the case of bank failure or other crisis events. Referring to the exact point in time of payment, initial payments at the beginning of a banks activity/membership, and regular (e.g. quarterly or annual) payments hereafter can be distinguished. While the former payments are made ex-ante / independently from any incident, additional funding could also take place ex post, i.e. in case of a trigger incident.

Sources: Contributions to the fund can stem from private sources - i.e. particularly the banks which deposits are covered - or/and public sources, which contribute public funds to help the deposit insurance institution function, or a combination of both (e.g. Demirgüç-Kunt \& Detragiache, 2002).

Calculation: A bank's precise contribution to any fund usually is calculated as a percentage of a certain charge base, such as the total volume of protected liabilities. From an economic point of view, risk-based premiums were preferable to address the problem of distorted incentives in an optimal way. However, most deposit insurance institutions still lack the expertise and resources to fulfil the extremely complex task of quantifying a bank's probability of default and its respective premium (what has been tried based on option pricing theory in particular, see the seminal contribution of Ronn \& Verma, 1986, and, recently, also Lee et al., 2015). Consequently, premium calculation of many deposit insurance systems represent a compromise between precise risk-sensitivity and manageability at best, e.g. by referring to a risk proxy (recently, Lakstutiene et al., 2018, with further references). Actually, the volume of insured deposits reflects part of the risk as seen by the deposit insurance institution, although it stands for the exposure at default only, not the probability of default.

\section{4) Administration}

Membership: In most countries, it is explicitly compulsory for a bank to participate in (i.e., contribute to, and have its depositors protected by) the national deposit insurance system (Demirgüç-Kunt et al., 2015). However, voluntary membership is not impossible, so that opaqueness of the membership principle can exist a fortiori.

Administration: Referring to the deposit insurance institution's management, public, private, and joint solutions are possible. Public administration means that the deposit insurance scheme is administered by a governmental authority of the country, which in particular could be the central bank, the supervisory 
authority, or a (publicly owned) separate deposit protection institution. Private administration implies that the institution administering the scheme is privately owned and that its management decisions are made by private representatives, at least formally without any influence of the central bank or other public authorities. Joint administration represents a middle way including representatives of public as well as private institutions.

\subsection{Comparison of current systems}

Subsequent Table 1 compares the features of the deposit insurance schemes of the analyzed countries according to the catalogue of criteria we elaborated in the previous chapter.

Table 1

Characteristics of deposit insurance system in post-Soviet countries as of December 2017

\begin{tabular}{|c|c|c|c|c|c|c|c|}
\hline & Belarus & Lithuania & Ukraine & Latvia & Estonia & Kazakhstan & Turkmenistan \\
\hline $\begin{array}{l}\text { Date of } \\
\text { establishmen } \\
t / \text { revisions }\end{array}$ & $\begin{array}{c}1996 / 1998 / 200 \\
8\end{array}$ & $\begin{array}{c}1996 / 2002 / 200 \\
9 / 2014\end{array}$ & $\begin{array}{c}1998 / 2001 / 201 \\
2 / 2015\end{array}$ & $\begin{array}{c}1998 / 2008 / 201 \\
0 / 2015\end{array}$ & $\begin{array}{c}1998 / 2002 / 201 \\
0 / 2016\end{array}$ & $\begin{array}{c}1999 / 2003 / 201 \\
4 / 2015\end{array}$ & 2000 \\
\hline Main goal & $\begin{array}{l}\text { Ensuring } \\
\text { guaranteed } \\
\text { payments for } \\
\text { the banking } \\
\text { deposits, } \\
\text { encouraging } \\
\text { trust to the } \\
\text { banking } \\
\text { system, } \\
\text { ensuring its } \\
\text { liquidity }\end{array}$ & $\begin{array}{c}\text { Ensuring } \\
\text { protection of } \\
\text { deposits and } \\
\text { liabilities to } \\
\text { investors in } \\
\text { case of banks' } \\
\text { failures, thus } \\
\text { contributing to } \\
\text { the higher } \\
\text { stability of } \\
\text { financial } \\
\text { markets and } \\
\text { society`s trust } \\
\text { in financial } \\
\text { institutions. }\end{array}$ & $\begin{array}{l}\text { Protecting } \\
\text { rights of bank } \\
\text { depositors, } \\
\text { stimulation of } \\
\text { trust to banks, } \\
\text { ensuring } \\
\text { liquidity and } \\
\text { solvency of } \\
\text { banking system, } \\
\text { calling off } \\
\text { insolvent banks } \\
\text { from the } \\
\text { market }\end{array}$ & $\begin{array}{l}\text { To guarantee } \\
\text { that depositors } \\
\text { are reimbursed } \\
\text { for the deposits } \\
\text { placed with the } \\
\text { deposit } \\
\text { guarantee } \\
\text { scheme } \\
\text { participants in } \\
\text { case of their } \\
\text { unavailability }\end{array}$ & $\begin{array}{l}\text { To guarantee } \\
\text { the protection } \\
\text { of funds of } \\
\text { depositors, } \\
\text { investors, unit- } \\
\text { holders, and } \\
\text { policyholders } \\
\text { of mandatory } \\
\text { funded } \\
\text { pensions, and } \\
\text { thereby to } \\
\text { increase the } \\
\text { reliability and } \\
\text { stability of the } \\
\text { financial sector }\end{array}$ & $\begin{array}{c}\text { Ensuring } \\
\text { financial system } \\
\text { stability } \\
\text { including } \\
\text { support of } \\
\text { confidence to } \\
\text { the banking } \\
\text { system by } \\
\text { paying out the } \\
\text { guaranteed sum } \\
\text { for depositors } \\
\text { (in the case of } \\
\text { bank } \\
\text { bankruptcy) }\end{array}$ & n.a. \\
\hline \multicolumn{8}{|l|}{$\begin{array}{l}\text { Other } \\
\text { functions* }\end{array}$} \\
\hline $\begin{array}{l}\text { The } \\
\text { possibility of } \\
\text { taking legal } \\
\text { actions against } \\
\text { the bank } \\
\text { including } \\
\text { intervening }\end{array}$ & Yes & No & Yes & No & No & Yes & No \\
\hline $\begin{array}{l}\text { The } \\
\text { possibility of } \\
\text { revoking } \\
\text { banking } \\
\text { license }\end{array}$ & Yes & Yes & Yes & No & No & Yes & No \\
\hline $\begin{array}{l}\text { Carrying out } \\
\text { the resolution } \\
\text { of insolvent } \\
\text { banks and } \\
\text { liquidation of } \\
\text { banks }\end{array}$ & Yes & No & Yes & No & No & Yes & No \\
\hline $\begin{array}{l}\text { Specificity } \\
\text { (Explicit/im } \\
\text { plicit form) }\end{array}$ & Explicit & Explicit & Explicit & Explicit & Explicit & Explicit & Explicit \\
\hline \multicolumn{8}{|l|}{$\begin{array}{l}\text { The scope of } \\
\text { coverage* }\end{array}$} \\
\hline $\begin{array}{l}\text { Individuals } \\
\text { deposits }\end{array}$ & Yes & Yes & Yes & Yes & Yes & Yes & Yes \\
\hline $\begin{array}{l}\text { Individuals- } \\
\text { entrepreneurs }\end{array}$ & No & $\begin{array}{l}\text { Yes (plus legal } \\
\text { entities) }\end{array}$ & Yes & $\begin{array}{l}\text { Yes (plus legal } \\
\text { entities) }\end{array}$ & Not specified & Yes & Not specified \\
\hline $\begin{array}{l}\text { Deposits in } \\
\text { foreign } \\
\text { currency }\end{array}$ & Yes & Yes & Yes & Yes & Yes & Yes & Not specified \\
\hline
\end{tabular}




\begin{tabular}{|c|c|c|c|c|c|c|c|}
\hline $\begin{array}{l}\text { Type of } \\
\text { deposits } \\
\text { covered }\end{array}$ & $\begin{array}{c}\text { Bank deposits } \\
\text { and bank } \\
\text { accounts }\end{array}$ & $\begin{array}{c}\text { Bank deposits, } \\
\text { liabilities to } \\
\text { investors }\end{array}$ & $\begin{array}{l}\text { Term deposits } \\
\text { means on } \\
\text { current } \\
\text { accounts, } \\
\text { deposit } \\
\text { certificates }\end{array}$ & $\begin{array}{l}\text { Term and } \\
\text { savings } \\
\text { deposits }\end{array}$ & Not specified & $\begin{array}{l}\text { Term and on } \\
\text { demand } \\
\text { deposits means } \\
\text { on payment } \\
\text { cards and } \\
\text { current } \\
\text { accounts }\end{array}$ & Not specified \\
\hline $\begin{array}{l}\text { Coverage } \\
\text { Amount }\end{array}$ & $\begin{array}{l}100 \% \text { of the } \\
\text { total deposit } \\
\text { amount in the } \\
\text { bank per } \\
\text { depositor }\end{array}$ & $\begin{array}{l}\text { up to EUR } \\
100000 \text { per } \\
\text { depositor (the } \\
\text { payout limit is } \\
\text { calculated for } \\
\text { each depositor } \\
\text { separately) }\end{array}$ & $\begin{array}{l}\text { UAH } 200000 \\
\text { (per individual, } \\
\text { including } \\
\text { principal and } \\
\text { interests) }\end{array}$ & $\begin{array}{l}\text { EUR } 100000 \\
\text { per depositor } \\
\text { of the bank (on } \\
\text { separate } \\
\text { occasions up to } \\
\text { EUR } 200000 \text { ) }\end{array}$ & $\begin{array}{c}\text { up to EUR } 100 \\
000 \text { per } \\
\text { depositor of } \\
\text { the bank }\end{array}$ & $\begin{array}{c}\text { KZT } 10 \mathrm{mln} / \\
\text { KZT } 5 \mathrm{mln} \\
\text { (for national } \\
\text { currency } \\
\text { deposits / } \\
\text { foreign } \\
\text { currency } \\
\text { deposits per } \\
\text { depositor) }\end{array}$ & $\begin{array}{c}100 \% \text { of } \\
\text { depositor's } \\
\text { amount in the } \\
\text { bank }\end{array}$ \\
\hline $\begin{array}{l}\text { includes } \\
\text { interest* }\end{array}$ & n.a. & Yes & Yes & Not specified & Yes & No & Not specified \\
\hline $\begin{array}{l}\text { Time of } \\
\text { compensatio } \\
\mathbf{n}\end{array}$ & $\begin{array}{l}\text { During } 1 \\
\text { month after the } \\
\text { applying for the } \\
\text { compensation } \\
\text { to the Agency. } \\
\text { Generally - up } \\
\text { to } 2 \text { years }\end{array}$ & $\begin{array}{l}\text { within } 20 \\
\text { working days } \\
\text { from the day of } \\
\text { the insured } \\
\text { event of } \\
\text { deposit; } \\
\text { generally } \\
\text { up to } 3 \text { months }\end{array}$ & $\begin{array}{l}\text { During the } \\
\text { period of } \\
\text { calling off the } \\
\text { bank from the } \\
\text { market (an } \\
\text { official } \\
\text { announcement } \\
\text { about the need } \\
\text { to register for } \\
\text { compensation } \\
\text { is made during } \\
\text { the } 30 \text { days } \\
\text { after liquidation } \\
\text { date) }\end{array}$ & up to 20 days & up to 20 days & $\begin{array}{c}\text { During } 14 \\
\text { working days } \\
\text { after the date } \\
\text { of bank } \\
\text { liquidation }\end{array}$ & up to 2 months \\
\hline $\begin{array}{l}\text { Funding } \\
\text { sources }\end{array}$ & Private & $\begin{array}{c}\text { Joint (private / } \\
\text { public) }\end{array}$ & $\begin{array}{c}\text { Joint (private / } \\
\text { public) }\end{array}$ & $\begin{array}{c}\text { Joint (private / } \\
\text { public) }\end{array}$ & $\begin{array}{c}\text { Joint (private / } \\
\text { public) }\end{array}$ & Private & Private \\
\hline $\begin{array}{l}\text { Contribution } \\
\mathrm{s} \text { to the fund: } \\
\text { initial and } \\
\text { annual } \\
\text { premium } \\
\text { ( } \% \text { of base) }\end{array}$ & $\begin{array}{c}\text { Initially } 0,5 \text { of } \\
\text { regulatory bank } \\
\text { capital } \\
\text { (normative); } \\
\text { regularly } 0,3\end{array}$ & $\begin{array}{l}0,45 \text { of the } \\
\text { amount of core } \\
\text { insured } \\
\text { deposits held } \\
\text { with the } \\
\text { participant of } \\
\text { the deposit } \\
\text { insurance } \\
\text { system }\end{array}$ & $\begin{array}{c}0,5 \text { in national } \\
\text { currency, } 0,8 \text { in } \\
\text { foreign } \\
\text { currency (or } \\
\text { the arithmetic } \\
\text { mean of the } \\
\text { sum of daily } \\
\text { balances on the } \\
\text { accounts of } \\
\text { deposits and } \\
\text { interest on } \\
\text { them for the } \\
\text { calculated } \\
\text { period) }\end{array}$ & $\begin{array}{c}\text { Initially - } 1,5 \text { of } \\
\text { share capital, } \\
0,05 \text { - of the } \\
\text { average amount } \\
\text { of deposits } \\
\text { covered which } \\
\text { were attracted } \\
\text { in the previous } \\
\text { quarter }\end{array}$ & $\begin{array}{l}\text { Initially - EUR } \\
3200 \text {, regularly } \\
\text { - up to 0,125 } \\
\text { (calculated on } \\
\text { the basis of the } \\
\text { total quarterly } \\
\text { amount of } \\
\text { deposits) }\end{array}$ & $\begin{array}{l}\text { up to } 0,5 \text { (for } \\
\text { usual calendar } \\
\text { premium, } \\
\text { depending on } \\
\text { the amount of } \\
\text { deposits } \\
\text { attracted by a } \\
\text { bank per } \\
\text { quarter) }\end{array}$ & n.a. \\
\hline $\begin{array}{l}\text { Possibility of } \\
\text { extra } \\
\text { funding } \\
\text { (special } \\
\text { premium)* }\end{array}$ & n.a. & n.a. & Yes & Yes & No & Yes & n.a. \\
\hline Membership & Compulsory & Compulsory & Compulsory & Compulsory & Compulsory & Compulsory & Compulsory \\
\hline $\begin{array}{l}\text { Administrati } \\
\text { on }\end{array}$ & Public & Public & Public & Public & $\begin{array}{c}\text { Public and } \\
\text { private }\end{array}$ & Public & Public \\
\hline
\end{tabular}

* Yes / No means that current option is adopted or established or present / not adopted.

Source: Websites of deposit insurance authorities in post-Soviet countries. 
Table 1 (continued)

Characteristics of deposit insurance system in post-Soviet Countries as of December 2017 (Part 2)

\begin{tabular}{|c|c|c|c|c|c|c|c|c|}
\hline & Uzbekistan & $\begin{array}{c}\text { Russian } \\
\text { Federation }\end{array}$ & Moldova & Armenia & Azerbaijan & Kyrgyzstan & Tajikistan & Georgia \\
\hline $\begin{array}{l}\text { Date of } \\
\text { establishment / } \\
\text { revisions }\end{array}$ & $2002 / 2009$ & $2003 / 2014$ & $\begin{array}{c}2003 / 2009 / 20 \\
10 / 2017\end{array}$ & $\begin{array}{c}2004 / 2008 / 20 \\
15\end{array}$ & $\begin{array}{c}2006 / 2009 / 20 \\
16\end{array}$ & $\begin{array}{c}2008 / 2009 / 20 \\
10 / \\
2013 / 2016\end{array}$ & $2011 / 2015$ & from 2018 \\
\hline Main goal & $\begin{array}{l}\text { Guaranteeing } \\
\text { payment of } \\
\text { deposits if the } \\
\text { bank loses its } \\
\text { license for } \\
\text { banking } \\
\text { operations }\end{array}$ & \begin{tabular}{|l|} 
Protecting \\
rights and legal \\
interests of \\
bank \\
depositors, \\
strengthening \\
trust into the \\
banking \\
system, \\
encouraging \\
attraction of \\
individuals' \\
savings into \\
the country's \\
banking \\
system \\
\end{tabular} & $\begin{array}{l}\text { Guaranteeing } \\
\text { deposits of } \\
\text { individuals in } \\
\text { banks which } \\
\text { have a license } \\
\text { of the } \\
\text { National bank } \\
\text { of Moldova }\end{array}$ & $\begin{array}{l}\text { Promote } \\
\text { reliable } \\
\text { banking } \\
\text { system, } \\
\text { enhance the } \\
\text { public } \\
\text { confidence in } \\
\text { the banking } \\
\text { system, protect } \\
\text { the interest of } \\
\text { depositors }\end{array}$ & $\begin{array}{l}\text { Protection of } \\
\text { financial } \\
\text { stability in the } \\
\text { country, } \\
\text { ensuring the } \\
\text { stability of } \\
\text { banking } \\
\text { system, } \\
\text { strengthening } \\
\text { depositors } \\
\text { confidence to } \\
\text { the banking } \\
\text { system }\end{array}$ & $\begin{array}{l}\text { Protection of } \\
\text { bank } \\
\text { depositors in } \\
\text { case of } \\
\text { guarantee } \\
\text { event } \\
\text { realization }\end{array}$ & $\begin{array}{l}\text { Protecting the } \\
\text { rights of } \\
\text { depositors by } \\
\text { paying out } \\
\text { insurance } \\
\text { sums, } \\
\text { strengthening } \\
\text { the confidence } \\
\text { of society in } \\
\text { the banking } \\
\text { system }\end{array}$ & n.a. \\
\hline \multicolumn{9}{|l|}{$\begin{array}{l}\text { Other } \\
\text { functions* }\end{array}$} \\
\hline $\begin{array}{l}\text { The possibility of } \\
\text { taking legal } \\
\text { actions against the } \\
\text { bank including } \\
\text { intervening }\end{array}$ & n.a. & No & No & Yes & Yes & Yes & Yes & n.a. \\
\hline $\begin{array}{l}\text { The possibility of } \\
\text { revoking banking } \\
\text { license }\end{array}$ & n.a. & No & No & No & No & No & No & n.a. \\
\hline $\begin{array}{l}\text { Carrying out the } \\
\text { resolution of } \\
\text { insolvent banks } \\
\text { and liquidation of } \\
\text { banks }\end{array}$ & n.a. & Yes & No & No & Yes & Yes & No & n.a. \\
\hline $\begin{array}{l}\text { Specificity } \\
\text { (Explicit/implic } \\
\text { it form) }\end{array}$ & Implicit & Explicit & Explicit & Explicit & Explicit & Explicit & Explicit & Implicit \\
\hline $\begin{array}{l}\text { Scope of } \\
\text { coverage* }\end{array}$ & & & & & & & & n.a. \\
\hline $\begin{array}{r}\text { Individuals } \\
\text { deposits }\end{array}$ & Yes & Yes & Yes & Yes & Yes & Yes & Yes & \\
\hline $\begin{array}{r}\text { Individuals- } \\
\text { entrepreneurs }\end{array}$ & No & Yes & No & Yes & No & No & Not specified & \\
\hline $\begin{array}{r}\text { Deposits in } \\
\text { foreign currency }\end{array}$ & Yes & Yes & Yes & Yes & Yes & Yes & Yes & \\
\hline $\begin{array}{r}\text { Type of deposits } \\
\text { covered }\end{array}$ & Not specified & $\begin{array}{c}\text { Bank deposits } \\
\text { means on bank } \\
\text { accounts }\end{array}$ & Not specified & $\begin{array}{l}\text { Any amount } \\
\text { provided by } \\
\text { the depositor, } \\
\text { funds on } \\
\text { accounts }\end{array}$ & Not specified & Not specified & Not specified & n.a. \\
\hline $\begin{array}{l}\text { Coverage } \\
\text { Amount }\end{array}$ & $\begin{array}{c}100 \% \text { of the } \\
\text { total deposit } \\
\text { amount in the } \\
\text { bank per } \\
\text { depositor }\end{array}$ & $\begin{array}{l}\text { RUB } 1400 \\
000 \text { (total } \\
\text { amount of } \\
\text { deposits per } \\
\text { depositor in } \\
\text { one bank) }\end{array}$ & $\begin{array}{c}\text { MDL } 6000 \text { per } \\
\text { depositor } \\
\text { irrespective of } \\
\text { other amounts } \\
\text { placed in a } \\
\text { bank }\end{array}$ & $\begin{array}{c}\text { Deposits in } \\
\text { AMD - AMD } \\
10 \text { mln per } \\
\text { depositor, in } \\
\text { foreign } \\
\text { currency - } \\
\text { AMD } 5 \text { mln } \\
\text { per depositor } \\
\text { (denominated) }\end{array}$ & $\begin{array}{c}100 \% \text { (but no } \\
\text { more than } \\
\text { AZN } 30000 \text { ). } \\
\text { In the next } 3 \\
\text { years, it is } \\
\text { planned to } \\
\text { cover } 100 \% \\
\text { of deposits per } \\
\text { depositor } \\
\text { without limits }\end{array}$ & $\begin{array}{l}\text { KGS } 100000 \\
\text { per individual }\end{array}$ & $\begin{array}{c}\text { up to } 350 \\
\text { indicators of } \\
\text { calculation per } \\
\text { depositor } \\
\text { (determined by } \\
\text { separate } \\
\text { legislation) }\end{array}$ & n.a. \\
\hline includes interest* & n.a. & Yes & Yes & Not specified & n.a. & Yes & Yes & n.a. \\
\hline $\begin{array}{l}\text { Time of } \\
\text { compensation }\end{array}$ & $\begin{array}{l}\text { During } 10 \\
\text { days after the } \\
\text { announcement } \\
\text { in media (plus } \\
\text { up to } 2 \\
\text { months of } \\
\text { collecting the } \\
\text { reserves) }\end{array}$ & $\begin{array}{l}7 \text { days after the } \\
\text { insured } \\
\text { accident - for } \\
\text { announcing } \\
\text { the conditions } \\
\text { to register for } \\
\text { compensation. } \\
30 \text { days - } \\
\text { register for } \\
\end{array}$ & up to 1 month & $\begin{array}{l}\text { up to } 3 \\
\text { months }\end{array}$ & $\begin{array}{l}7 \text { days for } \\
\text { announcing } \\
\text { information in } \\
\text { media. After } \\
\text { announcement } \\
\text { - up to } 1 \text { year } \\
\text { for registering } \\
\text { depositors. Up } \\
\text { to } 3 \text { months to } \\
\end{array}$ & $\begin{array}{l}\text { up to } 1 \text { month } \\
\text { after guarantee } \\
\text { event }\end{array}$ & up to 1 year & n.a. \\
\hline
\end{tabular}




\begin{tabular}{|c|c|c|c|c|c|c|c|c|}
\hline & & $\begin{array}{l}\text { compensation. } \\
3 \text { days - for } \\
\text { compensation } \\
\text { according to } \\
\text { provided } \\
\text { documents } \\
\end{array}$ & & & $\begin{array}{l}\text { pay out the } \\
\text { deposit sum } \\
\text { after } \\
\text { registration }\end{array}$ & & & \\
\hline Funding sources & $\begin{array}{c}\text { Joint (private / } \\
\text { public) }\end{array}$ & $\begin{array}{l}\text { Joint (private / } \\
\text { public) }\end{array}$ & $\begin{array}{l}\text { Joint (private / } \\
\text { public) }\end{array}$ & $\begin{array}{l}\text { Joint (private / } \\
\text { public) }\end{array}$ & Private & \begin{tabular}{|c|} 
Government - \\
$76 \%$, banks - \\
$24 \%$
\end{tabular} & $\begin{array}{c}\text { Joint (private / } \\
\text { public) }\end{array}$ & n.a. \\
\hline $\begin{array}{l}\text { Contributions to } \\
\text { the fund: initial } \\
\text { and annual } \\
\text { premium } \\
\text { ( } \% \text { of base) }\end{array}$ & $\begin{array}{l}\text { Initially, } 0,1 \text { of } \\
\text { share capital; } \\
\text { regularly up to } \\
0,5 \text { of the } \\
\text { number of } \\
\text { deposits } \\
\text { attracted in the } \\
\text { quarter (stops } \\
\text { when sum } \\
\text { reaches } 5 \% \text { of } \\
\text { deposits) }\end{array}$ & $\begin{array}{c}\text { up to } 0,15 \text {; in } \\
\text { emergency up } \\
\text { to } 0,3 \text { (of the } \\
\text { chronological } \\
\text { mean of the } \\
\text { sum of daily } \\
\text { balances on } \\
\text { the accounts } \\
\text { of deposits for } \\
\text { the calculated } \\
\text { period) }\end{array}$ & $\begin{array}{c}\text { Initially - 0,1 } \\
\text { of share } \\
\text { capital, } 0,25 \text { - } \\
\text { quarterly } \\
\text { (payments are } \\
\text { made until } 7 \% \\
\text { of registered } \\
\text { deposits in the } \\
\text { system is } \\
\text { reached) }\end{array}$ & $\begin{array}{c}\text { Initially - } \\
\text { AMD } 15 \text { mln., } \\
0,05- \\
\text { regularly of the } \\
\text { average daily } \\
\text { figure of } \\
\text { individuals' } \\
\text { including sole } \\
\text { proprietors' } \\
\text { bank deposits } \\
\text { of the bank in } \\
\text { a reporting } \\
\text { quarter } \\
\end{array}$ & $\begin{array}{l}\text { The first year } \\
0,15 \text { of the } \\
\text { daily residual } \\
\text { amount of } \\
\text { protected } \\
\text { deposits per } \\
\text { quarter, next } \\
\text { years } 0,125 \\
\text { quarterly }\end{array}$ & $\begin{array}{c}\text { Initially - } 1 \text { of } \\
\text { share capital, } \\
0,2 \text { - regularly } \\
\text { of total deposit } \\
\text { base per year }\end{array}$ & $\begin{array}{c}\text { Initially - } 0,5 \\
\text { of share } \\
\text { capital, } 0,25- \\
\text { regularly of the } \\
\text { average } \\
\text { amount of } \\
\text { deposit } \\
\text { balances in the } \\
\text { previous } \\
\text { quarter }\end{array}$ & n.a. \\
\hline $\begin{array}{l}\text { Possibility of } \\
\text { extra funding } \\
\text { (special } \\
\text { premium)* }\end{array}$ & n.a. & Yes & Yes & Yes & $\begin{array}{l}\text { up to } 0,2 \text { of } \\
\text { the daily } \\
\text { residual value } \\
\text { of protected } \\
\text { deposits }\end{array}$ & Yes & Yes & n.a. \\
\hline Membership & n.a. & Compulsory & Compulsory & Compulsory & Compulsory & Compulsory & Compulsory & n.a. \\
\hline Administration & Public & Public & Public & Public & $\begin{array}{c}\text { Joint (private / } \\
\text { public) }\end{array}$ & $\begin{array}{c}\text { Public and } \\
\text { private }\end{array}$ & Public & n.a. \\
\hline
\end{tabular}

* Yes / No means that current option is adopted or established or present / not adopted.

Source: websites of deposit insurance authorities in post-Soviet countries

Source: Authors' own compilation based on websites of deposit insurance authorities of post-Soviet countries

Our basic finding is, that - in contrast to the assumed attractiveness of deposit insurance for policymakers - post-Soviet countries began to include their national deposit protection schemes into their banking systems with considerable delay after gaining their independence. One of the first post-Soviet countries that officially implemented deposit insurance was Ukraine in 1998, although Belarus started the very process in 1996 already, but finished later (About guarantees of saving funds of individuals in foreign currency on the accounts and deposits in banks of the Republic of Belarus, 1998). Finally, Tajikistan adopted deposit insurance not before 2011, while Georgia now prepares a respective rule-making to finally start implementation from 2018 on. Based on this outline history, our first and basic hypothesis of immediate establishment is rejected. Further comparative analysis of current deposit protection schemes in post-Soviet countries shows the coexistence of 15 nationally specific approaches. Being outcomes of the institutional change in independent countries and financial systems, we expect the systems to differ in detail, but similarities of the general patterns comparing the layout of these systems produces findings as follows.

- Economic conditions in all countries after the break-up of the Soviet Union provided equal starting positions for the development of deposit guarantee systems insofar as they started from scratch. Thus, the absence of well-established institutions, knowledge, and processes, combined with a tradition of complicated and slow decision-making, even pressing problems were addressed reluctantly. Consequently, deposit insurance, which depended on the evolution of banking as well as political institutions, evolved with visible time-lags.

- Originally, government and central bank were the main actors driving the evolution of deposit insurance, while non-governmental / independent deposit insurance institutions and their respective legal basis were delayed. 
- Countries with large and fast growing economies in general (e.g. Belarus, Russian Federation, Ukraine, Kazakhstan) experienced a faster development of their financial sector in particular, making deposit insurance more urgent, thus reducing delays.

- The geographical position as well as relations with neighbour countries significantly influence the direction and speed of deposit insurance development in post-Soviet countries. For example, the Baltic countries, Ukraine and Moldova have chosen an EU integration vector that stipulated the adoption of the necessary measures of deposit insurance (such as independent deposit insurance institutions, gradual increases of coverage limits, expanding the categories of covered deposits, et al.) to meet the requirements of EU authorities and become closer to world leading standards.

Moving back to the criteria outlined in previous chapter, the results of a detailed analysis of deposit insurance in countries can be summarized as follows:

1) General purpose and specificity

While the most widespread main goals of deposit protection schemes are to support (1) depositors who are considered protection-worthy and (2) the (stability of the national) financial system as a whole, the schemes of some countries are characterized by wider ranges of responsibilities and obligations. In Ukraine, Belarus, and Kazakhstan, the fund is part of the supervisory architecture insofar as it is allowed to carry out functions concerning the procedure of calling-off insolvent banks from the market, revoking their banking license and managing banks which are going bankrupt. Almost every post-Soviet country has an explicit form of deposit insurance system, while only Uzbekistan and Georgia - which has not finished the implementation of its system yet - still have an implicit form. Although institutionalized in most of the countries analyzed, conditions of deposit insurance are changing continuously, leading to revisions of the current system. Thus, 3 out of 15 post-Soviet countries have revised their deposit protection scheme in 2016, including changes in time compensation, public authorities' functions, contributions etc., while in 2017 there were no significant changes among countries.

2) Coverage

Covered claims always include deposits of individual owners, in some countries also those of individual entrepreneurs (Russian Federation, Kazakhstan, Lithuania, Latvia, Armenia, and, since 2017, Ukraine). Only in Lithuania and Latvia, the deposits of legal entities are also covered, making the approaches of these countries significantly different from those of others. Additionally, the coverage limit varies depending on the set of criteria such as type of deposit, type of subject (individuals / entrepreneurs / legal entities), currency etc. Thus, in Kazakhstan and Armenia the coverage amount is twice as high for deposits in national currency than in foreign currency. In Ukraine, Lithuania, Estonia, Russian Federation, Moldova, Kyrgyzstan, Tajikistan, interests on deposits are covered, too, while in Kazakhstan they are not included. Despite international standards, covered amounts in post-Soviet countries mainly relate to banks and do not include other financial institutions (e. g. credit unions). At the same time, the excluding of interbank deposits follows international standards according to banks being financial professionals that are not particularly protectionworthy. Meanwhile, the coverage limit in most post-Soviet countries is not differentiated and presented as a fixed amount of compensation which a depositor will receive in case of insurance case occurs.

In most post-Soviet countries, the scheduled period of compensation of clients is rather short. The shortest compensation periods can be found in Kazakhstan (14 days after bank liquidation) and Latvia and Estonia (up to 20 days, gradually moving to the period of up to 7 days), opposed to the longest in Tajikistan (up to 1 year) and Belarus (up to 2 years). Meanwhile, the average scheduled time of compensation in postSoviet countries is close to 2 months after the official date of bank liquidation and registering of depositors and their claims.

3) Funding 
The majority of post-Soviet deposit protection schemes is funded by governmental and banks' contributions combined. However, the greater part of the funding is supported by the member banks, while governmental contributions are limited to emergencies. Member institutions have to make a compulsory initial, regular, and sometimes even special contributions to the fund. The details of determining the individual premium percentage procedure are part of national legislation. Turkmenistan, Belarus, Kazakhstan and Azerbaijan run deposit insurance systems that are exclusively based on private funding, i.e. payments of banks and other financial institutions only.

Although differing in detail, all of the post-Soviet deposit protection institutions follow a volume-based approach to premium calculation. Consequently, premiums are either not or just tentatively risk-based. However, as a deposit insurance institution is facing a particular expected loss (EL) represented by a covered bank, this implies a severe violation of the principles of insurance. As the EL is defined as EL = PD x EAD $\mathrm{x}$ LGD, it is of interest in how far these factors are considered. While the probability of default (PD) of a member bank is disregarded by any scheme, some of them at least refer to the exposure at default (EAD) and the loss given default (LGD) of an insured bank, insofar as the volume of covered deposits serves as the reference basis of the premium. EAD-based-premiums of this kind is collected by the deposit insurance institutions of e.g. Lithuania and Estonia. On the contrary, the systems of e.g. Ukraine, Kazakhstan, and the Russian Federation appear purely volume-based, as they calculate premiums as a percentage of - naturally unprotected - shareholder's capital, but no insured volumes. Although a bank's equity represents its seminal risk buffer, relating it to its PD requires knowledge not only of the amount of equity but also of the risk exposure of a bank. Consequently, referring to the amount of equity only does not create a PD-/risk-basedpremium.

4) Administration

In all post-Soviet countries, participation in the deposit insurance system is compulsory for banks. Referring to the administrative body, the third way of joint administration, which involves private and public actors alike used to be the most common among post-Soviet countries. Meanwhile, most of them have switched to public administration, as it is regarded as the most reliable way of maintaining the efficiency of a deposit insurance system in unstable economic surroundings (Talley \& Mas, 1980). In detail, the management of deposit insurance mechanisms in post-Soviet countries appears to be complicated, as numerous countries are still revising the relevant rules and organizations. Meanwhile, the deposit insurance institutions of 12 out of 15 countries have an official management body, either as a separate legal entity or as a part of the country's supervisory structure, such as the national central bank, the Ministry of Finance or the Department of Treasury. Only the protection schemes of Azerbaijan, Kyrgyzstan, and Estonia rely on joint management procedures allowing issues of depositor protection to be managed not only by official bodies but in cooperation with representatives of private owners of (the non-insolvent) banks.

Comparative analysis shows a rather heterogeneous landscape of deposit insurance in post-Soviet countries. However, the current heterogeneity could be mitigated in several ways, one of them set by several of these countries attempting to become EU member states. In the case of success, they had to align among numerous other institutions - their national deposit insurance schemes to respective EU rules and regulations.

Of all the post-Soviet countries, so far only the Baltic states of Latvia, Lithuania and Estonia have become members of the EU (in 2004, see Poissonnier, 2017), while Georgia, Moldova, and Ukraine became associate members in 2014 (as an overview, Nodia et al., 2017).). At first, this helps to explain the similarities of the deposit protection schemes of the three Baltic countries. Secondly, it means that it is worthwhile to analyze in how far the systems of the associate members already comply with EU law - or are destined to be amended respectively. To approximate the EU standard not necessarily means the perfect copying of an EU blueprint: Regulating deposit protection, the EU applies the principle of minimum requirements, 
allowing member countries to have systems that offer a higher level of protection than the one defined by EU law (in general on the challenge of "customization" ("goldplating") of EU directives, see, extensively, Thomann \& Zhelyazkova, 2017). As the Georgian deposit insurance approach is still evolving, so that data on several features is not obtainable yet, we limit our analysis to the systems of Moldova and Ukraine. The results of a comparison of their deposit protection mechanisms with EU standards can be found in Table 2 .

Table 2

Main differences between deposit insurance systems in EU member states and EU associate member states (as of December 2017)

\begin{tabular}{|c|c|c|c|}
\hline Features & EU & Ukraine & Moldova \\
\hline Legislative basis & $\begin{array}{l}\text { Directive } 94 / 19 / \mathrm{EC} \text { of } 30.05 .1994 \text {, } \\
\text { revised } 2014\end{array}$ & $\begin{array}{l}\text { Law of Ukraine 'About the deposit } \\
\text { guarantee system of individuals' No. } \\
4452 \text { of } 23.02 .2012\end{array}$ & $\begin{array}{l}\text { The Law 'About guaranteeing } \\
\text { deposits of individuals in the banking } \\
\text { system" No. } 575 \text { of } 26.12 .2003\end{array}$ \\
\hline $\begin{array}{l}\text { Sources of } \\
\text { funding }\end{array}$ & Private (no funds of taxpayers) & Joint (private / public) & Joint (private / public) \\
\hline $\begin{array}{l}\text { Coverage } \\
\text { amount }\end{array}$ & EUR 100,000 & UAH 200,000 (EUR 5,970) & MDL 6,000 (EUR 294) \\
\hline $\begin{array}{l}\text { Covered } \\
\text { deposits }\end{array}$ & $\begin{array}{l}\text { All deposits, including deposits of } \\
\text { individuals, individual entrepreneurs, } \\
\text { and companies }\end{array}$ & $\begin{array}{l}\text { All deposits of individuals and } \\
\text { individual entrepreneurs }\end{array}$ & All deposits of individuals \\
\hline $\begin{array}{l}\text { Initial and } \\
\text { annual premium }\end{array}$ & $\begin{array}{l}\text { By } 3 \text { July } 2024 \text {, the available financial } \\
\text { means of a deposit guarantee system } \\
\text { should reach a target level of at least } 0.8 \\
\% \text { of the amount of the covered } \\
\text { deposits of its members (or about } € 55 \\
\text { billion) }\end{array}$ & $\begin{array}{l}0,5 \% \text { in national currency, } 0,8 \% \text { in } \\
\text { foreign currency (of the arithmetic } \\
\text { mean of the sum of daily balances } \\
\text { on the accounts of deposits and } \\
\text { interest on them for the calculated } \\
\text { period), the total amount of Fund is } \\
\text { not less than } 2.5 \% \text { of all guarantee } \\
\text { deposits }\end{array}$ & $\begin{array}{l}\text { Initially - } 0,1 \% \text { of share capital, } 0,25 \\
\% \text { - quarterly (payments are made } \\
\text { until } 7 \% \text { of registered deposits in } \\
\text { system is reached) }\end{array}$ \\
\hline $\begin{array}{l}\text { Time limit of } \\
\text { compensation }\end{array}$ & $\begin{array}{l}\text { Up to } 20 \text { working days after the date: } \\
\text { - on which a relevant administrative } \\
\text { authority makes a determination that the } \\
\text { credit institution is not able to repay the } \\
\text { deposit and it has no current prospect of } \\
\text { being able to do so or } \\
\text { - a judicial authority has made a ruling } \\
\text { for reasons which are directly related to } \\
\text { the credit institution's financial } \\
\text { circumstances and which has the effect } \\
\text { of suspending the rights of depositors to } \\
\text { make claims against it. }\end{array}$ & $\begin{array}{l}\text { Up to } 1 \text { month after the date of } \\
\text { making a decision of the National } \\
\text { bank of Ukraine to withdraw the } \\
\text { banking license of the bank and } \\
\text { start its liquidation }\end{array}$ & $\begin{array}{l}\text { Up to } 1 \text { month after the date of } \\
\text { withdrawal of banking license of the } \\
\text { bank and start of its liquidation }\end{array}$ \\
\hline
\end{tabular}

Source: Authors' own compilation based on legislation of the EU (Directive 2014/49/EU), of Ukraine (On the System of Guaranteeing Natural Person Deposits, 2012) and of the Republic of Moldova (About the guaranteeing of individuals' deposits in the banking system, 2003) on deposit insurance

In general, the deposit insurance systems of the two associate EU members appear rather close to EU requirements, while the main differences consist of only a few, but significant points. The subsequent list illustrates that some of the differences are shortcomings, some are over-achievements of EU requirements:

Coverage:

- Deposit insurance in Ukraine and Moldova covers only deposits of individuals excluding deposits of (at least selected) legal persons/institutions.

- While EU rules set a minimum fund size of $0.8 \%$ of covered deposits, Ukrainian (Moldovian) rules call for a level of $2.5 \%(7 \%)$.

- The covered amount of deposits per depositor and per bank in Ukraine (UAH 200,000, i.e. about EUR 6,000) and Moldova (MDL 6,000, i.e. about EUR 290) is much lower than the minimum amount, which the directive sets for EU member countries (EUR 100,000).

Funding: 
- The EU rules call for contributions of banks based on (1) the volume of covered deposits according to the bank's balance sheet and (2) the bank's risk exposure, so that the contributions are risk-based in a general sense, as they refer to the exposure at default and (a proxy for) the probability of default as seen by the protection scheme. Compared herewith, contributions to the Ukrainian or the Moldavian scheme are a flat rate in the sense of being not risk-based.

Obviously, the Ukrainian and the Moldavian systems undercut EU minimum requirements in several respects, in particular regarding the level of coverage. However, one of the most crucial differences between the EU member states and its current associate members is the level of individual economic wealth including bank deposits. Therefore, even a lower Euro amount covered by the system could mean that it covers a percentage of deposits that complies with EU rules. We further illustrate the sufficiency of one of the associate member states' systems by exploring the case of Ukraine.

\section{COMPATIBILITY OF THE UKRAINIAN DEPOSIT INSURANCE SCHEME}

If a country decides to attempt to join supranational institutions, a new institutional framework becomes relevant. Thus, those post-Soviet countries that have decided to attempt joining the European Union, have to take EU law into account. In the context of this paper, the particular question arises in how far current EU-oriented post-Soviet countries have EU-compatible systems of deposit insurance. Respective analysis could include the countries of Georgie, Moldova, and Ukraine.

Recent political events in Ukraine have forced the start of extended economic reforms combined with reformation of the financial sector according to the euro integration direction established by Ukrainian government. Thus, after the Revolution of Dignity of 2014, the National Bank of Ukraine initiated reforming the banking sector based on the Complex Program of Development of Financial Sector of Ukraine by 2020. In 2017, the first stage of reforms was completed. Nearly 90 insolvent banks were removed from the market, the depositors of these banks received compensation from the Ukrainian Deposit Guarantee Fund. Second, significant recapitalizations of banks were carried out, the minimum share capital requirements for new banks were increased from UAH 120 million (EUR 3,8 million) to UAH 500 million (EUR 15,9 million). Internal transformation of the National Bank of Ukraine favored in its contribution of UAH 144,4 billion (EUR 4,6 billion) to the State Budget of Ukraine in 2014-2016. Finally, the design of the Guarantee Fund was improved, including the establishment of an office responsible for the liquidization of assets of insolvent banks.

After excluding Georgia according to the unfinished status of its deposit insurance scheme, we also exclude Moldova due to the lowest level of deposit coverage in Europe and foreseeable amendments of the country's legislation on and design of deposit insurance, which take into account the latest recommendations of IMF experts following the evaluation of the financial system (e.g. pointing at an increase of coverage limits, or expansion of deposit categories covered). Instead we focus on Ukraine for the following reasons:

The Ukrainian system was established earlier and has been adjusted several times, converging international best practices. In particular, the Ukrainian government promptly reacted to the 2008 financial crisis and adopted new rules allowing the national deposit insurance institution the removing of insolvent banks from the market. Since 2014, requirements on informing clients about deposit insurance were expanded. By 2015, the time allowed for compensation payments was reduced. By 2017, the coverage was extended to individuals-entrepreneurs. Finally, although differing from international standards in absolute numbers, the amount covered is meets those standards when put into perspective, i.e. when the ratio coverage amount of deposit / GDP per capita is taken into account.

The basics of the Ukrainian Deposit Guarantee Fund (DGF) are included in Table 1. The DGF's structure, which is closely related to its coverage and funding, is illustrated in Figure 4. 


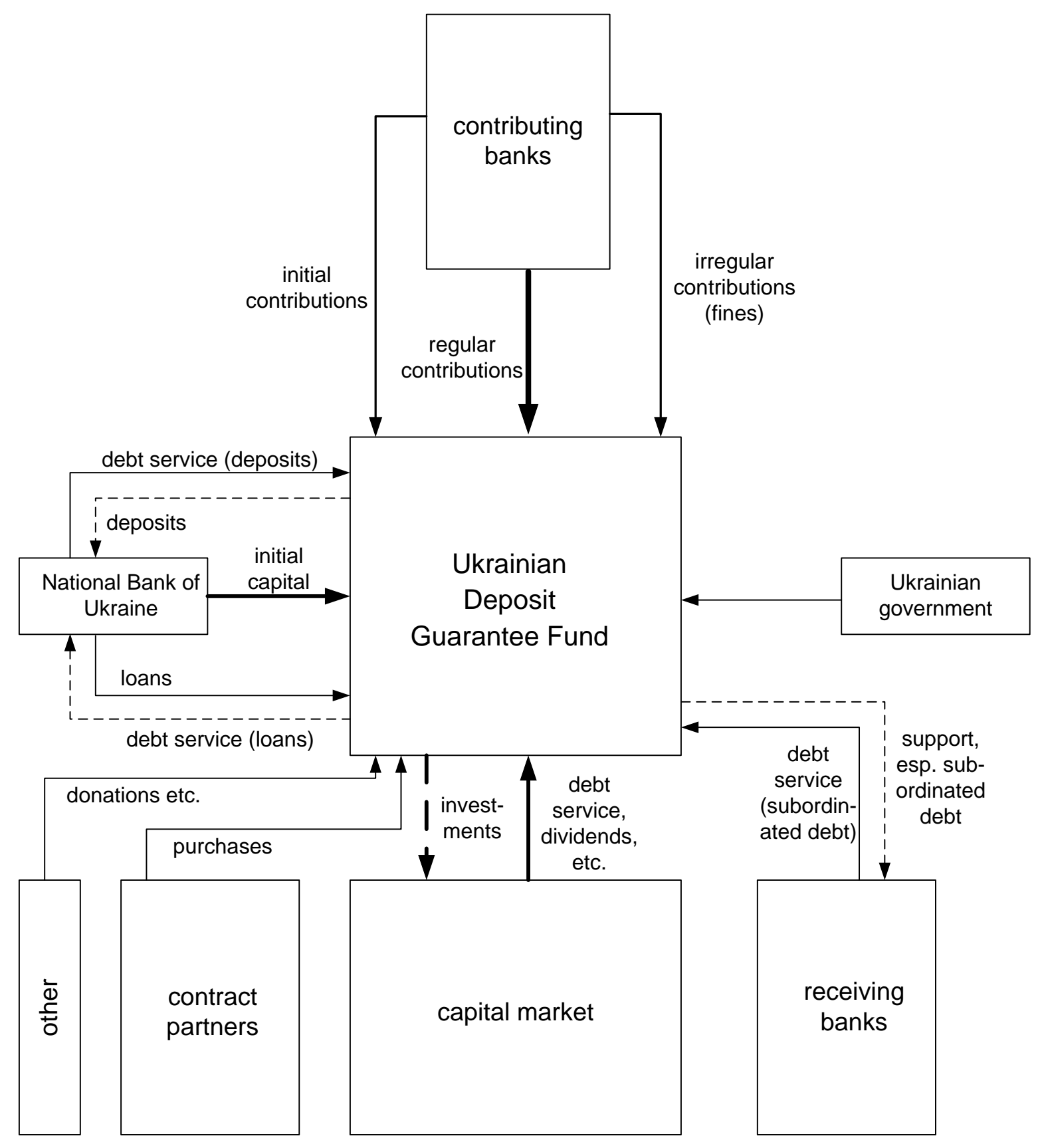

Figure 4. Peculiarities of the Ukrainian Deposit Guarantee Fund

Source: Authors' own diagram

According to Ukrainian legislation (On the System of Guaranteeing Natural Person Deposits, 2012; see also About measures to protect the rights of individual depositors of commercial banks in Ukraine, 1998) membership and contributing to the fund is compulsory for any licensed bank. As of 01.01.2018, the Deposit Guarantee Fund included 83 Ukrainian banks, for whose customers it held a reserve amount of UAH 14,4 billion (i.e., about EUR 477,42 million). While the fund's key ratios grew constantly from the beginning, this development was severely distorted by the annexation of Crimea and the subsequent (economic) crisis, which led to a decline of contributing banks, deposits, and fund reserves. Table 3 provides an overview of selected quantitative features of the Ukrainian DGF which are key to its capabilities. 
Key ratios of the Ukrainian Deposit Guarantee Fund

\begin{tabular}{|c|c|c|c|c|c|c|c|c|c|c|c|c|c|c|c|c|c|}
\hline & 2001 & 2002 & 2003 & 2004 & 2005 & 2006 & 2007 & 2008 & 2009 & 2010 & 2011 & 2012 & 2013 & 2014 & 2015 & 2016 & 2017 \\
\hline $\begin{array}{l}\text { Number of } \\
\text { licensed } \\
\text { banks }\end{array}$ & 135 & 157 & 157 & 160 & 165 & 170 & 175 & 184 & 182 & 176 & 176 & 175 & 179 & 163 & 120 & 100 & 82 \\
\hline $\begin{array}{l}\text { Number of } \\
\text { participating } \\
\text { banks }\end{array}$ & 135 & 152 & 153 & 160 & 163 & 166 & 172 & 183 & 184 & 175 & 175 & 174 & 178 & 161 & 118 & 99 & 83 \\
\hline $\begin{array}{l}\text { The volume } \\
\text { of deposits } \\
\text { (covered), in } \\
\text { EUR million }\end{array}$ & 1.93 & 3.29 & 4.84 & 5.80 & 10.66 & 15.83 & 22.42 & 26.58 & 18.18 & 24.09 & 25.52 & 32.95 & 37.92 & 24.36 & 14.98 & 13.50 & 13.76 \\
\hline $\begin{array}{l}\text { Fund } \\
\text { reserves, in } \\
\text { EUR million }\end{array}$ & 14.30 & 30.84 & 40.25 & 61.50 & 98.87 & 136.74 & 192.91 & 387.45 & 395.02 & 321.24 & 435.89 & 593.09 & 686.99 & 1075.83 & 582.23 & 541.19 & 477.42 \\
\hline $\begin{array}{l}\text { Banks } \\
\text { whose } \\
\text { customers } \\
\text { received } \\
\text { fund } \\
\text { payments }\end{array}$ & 2 & 2 & 4 & 4 & 5 & 8 & 8 & 9 & 9 & 17 & 18 & 22 & 24 & 28 & 33 & 13 & 9 \\
\hline $\begin{array}{l}\text { Fund } \\
\text { payments, in } \\
\text { EUR million }\end{array}$ & 6.92 & 0.50 & 1.18 & 0.59 & 3.14 & 23.20 & 15.25 & 34.45 & 96.77 & 217.33 & 17.26 & 51.80 & 111.67 & 539.39 & 940.06 & 415.81 & 234.78 \\
\hline
\end{tabular}

Sources: Authors`calculations, The Guarantee Fund of Individuals’ Deposits (www.fg.gov.ua), National Bank of Ukraine (http://www.bank.gov.ua)

Since the early years, the DGF's nominal coverage amount per depositor has increased from UAH 500 in 1998 to UAH 200,000 (since 2012). Despite this excessive increase, the level of coverage has, in fact, dropped when denominated in EUR, due to the considerable devaluation of the Ukrainian currency, as subsequent Fig. 5 shows. Thus, the Ukrainian coverage level measured in EUR undercuts EU minimum requirements considerably.

While the Ukrainian limit of coverage thus seems not too convincing from an $\mathrm{EU}(\mathrm{R})$ point of view, it has to be put into perspective - in particular with regard to the size of average deposits and income. During 2015 , the first indicator was within a range of $98.7 \%-98.8 \%$, which means that only $1.2-1.3 \%$ of the total amount of deposits in Ukraine were not covered by the UAH 200,000 limit of the DGF.

To put the absolute coverage level further into perspective, it can also be compared with macroeconomic figures. For this purpose, the amount of insurance coverage usually is put into relation to GDP per capita (Demirgüç-Kunt et al., 2015; Garcia, 1999; Laeven, 2004). As a benchmark, the BIS suggested that the coverage level should be about the triple amount of GDP per capita (Ngo et al., 2016; Financial Stability Forum - Basel, 2001). The current ratio of coverage amount of deposit to GDP per capita in Ukraine is presented in Table 4. 


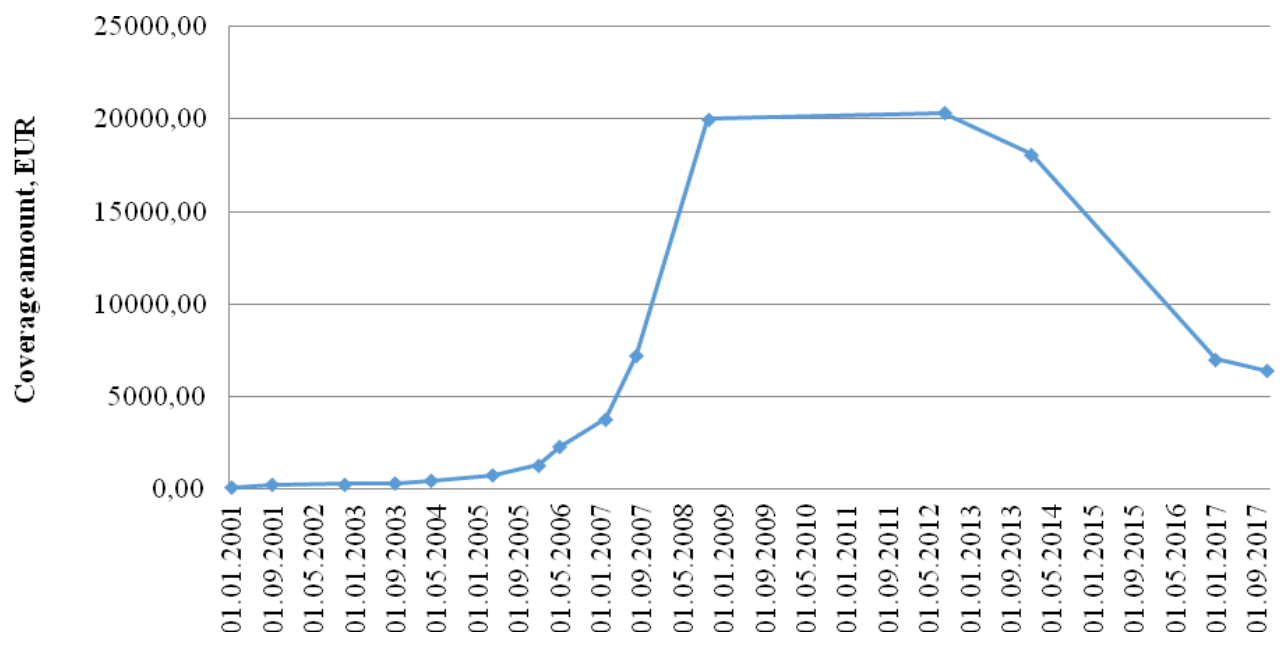

Figure 5. Development of coverage amount by the Ukrainian Deposit Guarantee Fund as denominated in EUR (2001-2017)

Source: The Guarantee Fund of Individuals' Deposits (www.fg.gov.ua)

Table 4

Coverage amount of deposit to GDP per capita in Ukraine in 2001-2017

\begin{tabular}{|c|c|c|c|}
\hline Date & GDP per capita, UAH & $\begin{array}{c}\text { Coverage amount of deposit, } \\
\text { UAH }\end{array}$ & $\begin{array}{c}\text { Coverage amount of deposit to GDP } \\
\text { per capita ratio, } \%\end{array}$ \\
\hline 01.01 .2001 & 3,441 & 500 & 14.53 \\
\hline 01.01 .2002 & 4,210 & 1,200 & 28.50 \\
\hline 01.01 .2003 & 4,685 & 1,500 & 32.02 \\
\hline 01.01 .2004 & 5,591 & 2,000 & 35.77 \\
\hline 01.01 .2005 & 7,273 & 3,000 & 41.25 \\
\hline 01.01 .2006 & 9,372 & 5,000 & 53.35 \\
\hline 01.01 .2007 & 11,630 & 15,000 & 128.98 \\
\hline 01.01 .2008 & 15,496 & 50,000 & 322.66 \\
\hline 01.01 .2009 & 20,495 & 150,000 & 731.89 \\
\hline 01.01 .2010 & 19,832 & 150,000 & 756.35 \\
\hline 01.01 .2011 & 23,600 & 150,000 & 635.59 \\
\hline 01.01 .2012 & 28,488 & 150,000 & 526.54 \\
\hline 01.01 .2013 & 30,953 & 200,000 & 646.14 \\
\hline 01.01 .2014 & 31,984 & 200,000 & 625.31 \\
\hline 01.01 .2015 & 35,834 & 200,000 & 558.13 \\
\hline 01.01 .2016 & 46,210 & 200,000 & 432.81 \\
\hline 01.01 .2017 & 56,250 & 200,000 & 355,56 \\
\hline 01.01 .2018 & 70,210 & 200,000 & 284,86 \\
\hline
\end{tabular}

Sources: Authors`calculations, The Guarantee Fund of Individuals’ Deposits (www.fg.gov.ua), World Bank Statistics (http://data.worldbank.org)

According to table 4, the coverage amount of deposits to GDP per capita in Ukraine has increased from about $15 \%$ as of 01.01 .2001 to a maximum of more than $700 \%$ in $2009 / 2010$. Although the ratio has dropped since then - as GDP per capita rose, while the coverage level remained stable -, its recent level of more than 4 still more than meets the suggested European standard.

Altogether, the Ukrainian DGF demonstrates its ability to cover deposits in case of banks failures in the country and can be considered an effective element of the countries depositor protection scheme: Today, the reserves of the Ukrainian DFG are sufficient to provide almost complete insurance for depositors of 
banks and meet international standards. Ukraine is gradually moving forward to the implementation of EU recommendations on deposit insurance, adopting amendments to current legislation continuously.

\section{CONCLUSIONS AND RECOMMENDATIONS}

Deposit insurance mechanisms represent one of the main pillars of the institutional framework of the development of the financial systems evolving in the post-Soviet countries since the 1990s. Meanwhile, almost all successor countries of the Soviet Union have established a national deposit protection scheme, sometimes even revised it several times. While the details vary, several patterns could be identified, including the prevalence of explicit deposit insurance, compulsory membership, joint private/public funding, and the prominent role of political decision-making.

Only a few of the post-Soviet countries (i.e., the Baltic countries) have already joined the EU and successfully implemented EU regulations, in particular on deposit insurance. As for the EU's current associate members, the national systems of Ukraine and Moldova are at least partly close to EU requirements (while the new Georgian system still awaits completion and evaluation). Put into perspective, even formal shortcomings seem to be tolerable from an economic point of view. Insofar, deposit insurance should pose no serious impediment for the countries' acceding the EU - however, the peculiarities of EU procedures could nevertheless lead to lengthy negotiations in this field. Furthermore, according to instability in the banking sector and decreasing clients `confidence in Ukrainian banks (Ngalawa et al., 2016; Savchenko, 2011; Vasilyeva \& Lunyakov, 2013) we can point out key instruments that implementation could further improve the effectiveness of the Ukrainian deposit insurance mechanism:

- Extension of coverage to include deposits of selected (corporate) institutions and other types of deposits under coverage too. In particular, deposits in bank metals are popular among individuals in Ukraine, but their coverage is not guaranteed according to the Law on deposit insurance;

- Inclusion of further financial institutions, especially other bank types (credit unions).

- Implementation of a compensation mechanism taking into account inflation factors, i.e. enhancing repayments in case of delay according to the inflation rate;

- Extension of a differentiated approach to establishing regular contributions by Fund participants. In Ukrainian legislation, it has been already pointed that this approach can be used by the decision of the Fund, but it should be used for all of the banks depending on the risk scale of their activity, not in only in some specific cases. Accordingly, banks that perform risky operations will make bigger contributions to the Fund that will increase its reserves and liquidity.

The Ukrainian experience in implementing the deposit guarantee system to some extent can be used by other post-Soviet countries which currently work on adopting or improving deposit insurance. At the same time, Ukraine needs to continue improving its deposit insurance system, even though it is closer to international standards than the systems of most other post-Soviet countries, to approximate particular EUstandards even closer.

In general, however, the problem of deposit insurance adoption in post-Soviet countries is still an urgent one already on its own. It becomes even more pressing when deposit insurance and banking regulation are considered as complementary parts of a regulatory system (Fungáčová et al., 2017). In particular, those countries which implemented only basic protection schemes so far should consider further revisions to enhance trust in their financial systems and to strengthen their international competitiveness, too. The latter becomes increasingly important in a world of global competition - and would be of extra importance if countries see their EU accession as a long-term option. Consequently, deposit insurance in post-Soviet countries will not cease to show institutional change and thus to offer interesting research questions in the future. 


\section{ACKNOWLEDGEMENT}

This work was supported by the DAAD - German Academic Exchange Service [DAAD Project 57243548].

\section{REFERENCES}

About insurance of deposits of individuals in banks of the Russian Federation (O страховании вкладов физических лии в банках Российской Федерачии) (2003). Federal Law of the Russian Federation No. 177-FL. Dec 23, 2003. Accessed Jun 1, 2017, http://www.consultant.ru/document/cons_doc_LAW_45769.

About measures to protect the rights of individual depositors of commercial banks in Ukraine (Про заходu щодо захисту npaв фiзuuнux осіб - вкладників комериійних банків Украӥни) (1998). Decree of the President of Ukraine № 996/98. Sep 10, 1998. Accessed Jun 1, 2017. http://search.ligazakon.ua/1_doc2.nsf/link1/U996_98.html.

About the guaranteeing of individuals' deposits in the banking system (о гарантировании депозитов физических лии в банковской системе) (2003). Law No. 575 (2003) of the Parliament of the Republic of Moldova. Dec 26, 2003. Accessed Jun 1, 2017. http://www.lex.justice.md/viewdoc.php?action=view\& view $=\mathrm{doc} \& \mathrm{did}=313219 \& \mathrm{lang}=2$.

About guarantees of saving funds of individuals in foreign currency on the accounts and deposits in banks of the Republic of Belarus (O гарантиях сохранности средств физических лич в иностранной валюте, находящихся на счетах и во вкладах (депозитах) в банках Республики Беларусь) (1998). Decree of the President of the Republic of Belarus No. 4. Apr 20, 1998. Accessed Jun 1, 2017. http://laws.newsby.org/documents/dekretp/dek00140.htm.

Allen, F., \& Gale, D. (2000). Comparing Financial Systems. Cambridge (Mass.) and London: The MIT Press.

Alyeksyeyev, I., \& Mazur, A. (2018). Adapting International Experience to the Deposit Guarantee System in Ukraine. Financial Sciences - Nauki o Finansach, 23(1), 9-21.

Arzhevitin, S. (2010). Why and how to reform the Deposit guarantee system. Visnyk of the National Bank of Ukraine, 177(11), 3-7.

Beck, T. (2003). The Incentive-Compatible Design of Deposit Insurance and Bank Failure Resolution Concepts and Country Studies. Policy Research Working Paper no. 3043, Washington, D.C.: The World Bank, Development Research Group - Finance Team.

Benston, G. J. (1998). Regulating Financial Markets: A Critique and some Proposals. Hobart Paper no. 135, London: Institute of Economic Affairs.

Calomiris, C. W. (1990). Is Deposit Insurance Necessary? A Historical Perspective. The Journal of Economic History, 50(2), 283-295.

Calomiris, C. W., \& White, E. N. (1994). The Origins of Federal Deposit Insurance. In C. Goldin \& G. D. Libecap (Eds.), The Regulated Economy: A Historical Approach to Political Economy (pp. 145-188). Chicago: University of Chicago Press.

Chan, Y.-S., Greenbaum, S. I., \& Thakor, A. V. (1992). Is Fairly Priced Deposit Insurance Possible? The Journal of Finance, 47(1), 227-245.

Chernykh, L., \& Cole, R. (2011). Does deposit insurance improve financial intermediation? Evidence from the Russian experiment. Journal of Banking \& Finance, 35, 388-402.

Cojocaru, L., Falaris, E. M., Hoffman, S. D., \& Miller, J.B. (2016): Financial System Development and Economic Growth in Transition Economies: New Empirical Evidence from the CEE and CIS Countries. Emerging Markets Finance \& Trade, 52(1), 223-236.

Cummins, J. D. (1988). Risk-Based Premiums for Insurance Guaranty Funds. The Journal of Finance, 43(4), 823-839.

Demirgüç-Kunt, A., \& Sobaci, T. (2001). Deposit insurance around the world. The World Bank Economic Review, 15(3), $481-490$

Demirgüç-Kunt, A., \& Detragiache, E. (2002). Does deposit insurance increase banking system stability? Journal of Monetary Economics, 49(7), 1373-1406.

Demirgüç-Kunt, A., \& Huizinga, H. (2004). Market discipline and deposit insurance. Journal of Monetary Economics, 51(2), 375-399.

Demirgüç-Kunt, A., \& Kane, E. J. (2002). Deposit Insurance around the Globe: Where Does It Work? The Journal of Economic Perspectives, 16(2), 175-195. 
Demirgüç-Kunt, A., Karacaovali, B., \& Laeven, L. (2005). Deposit insurance around the world: a comprehensive database. World Bank Policy Research Working Paper 3628, June 2005, Washington, D.C.: The World Bank, Development Research Group - Finance Team.

Demirgüç-Kunt, A., Kane, E. J., \& Laeven, L. (2008a). Determinants of Deposit-Insurance Adoption and Design. Journal of Financial Intermediation, 17(3), 407-438.

Demirgüç-Kunt, A., Kane, E. J., \& Laeven, L. (2015). Deposit insurance around the world: a comprehensive analysis and database. Journal of Financial Stability, 20(10), 155-183.

Demirgüç-Kunt, A., Kane, E. J., \& Laeven, L. (eds., 2008b). Deposit Insurance Around the World: Issues of Design and Implementation. Cambridge (Mass.) and London: The MIT Press.

Diamond, D., \& Dybvig, P. (1983). Bank Runs, Deposit Insurance, and Liquidity. Journal of Political Economy, 91 (3), 401419.

Directive 94/19/EU of the European Parliament and of the Council of 30 May 1994 on deposit-guarantee schemes. Official Journal of the European Union L 135, 31/05/1994, 5-14.

Directive 2009/14/EC of the European Parliament and of the Council of 11 March 2009 amending Directive 94/19/EC on deposit-guarantee schemes as regards the coverage level and the payout delay. Official Journal of the European Union L 68, 13/03/2009, 3-7.

Directive 2014/49/EU of the European Parliament and of the Council of 16 April 2014 on deposit guarantees schemes. Official Journal of the European Union L 173, 12/06/2014, 149-178.

Dovgan, J. (2012) Financial stability of the banking system of Ukraine (doctoral dissertation). The State Higher Educational Institution Ukrainian Academy of Banking of the National Bank of Ukraine, Sumy, Ukraine.

Financial Stability Forum (2001). Guidance for developing effective deposit insurance systems, Basel: FSF.

Fungáčová, Z., Weill, L., \& Zhou, M. (2017). Bank Capital, Liquidity Creation and Deposit Insurance. Journal of Financial Services Research, 51, 97-123.

Garcia, G. (1999). Deposit Insurance: A Survey of Actual and Best Practices. IMF Working Paper No. 99/54, Washington, D.C.: International Monetary Fund.

Gerhardt, M., \& Lannoo, K. (2011). Options for Reforming Deposit Protection in the EU. ECRI Policy Brief No. 4, Brussels: European Credit Research Institute.

Goodman, L. S., \& Shaffer, S. (1984). The Economics of Deposit Insurance: A Critical Evaluation of Proposed Reforms. Yale Journal on Regulation, 2(1), 145-162.

Golembe, C. H. (1960). The Deposit Insurance Legislation of 1933 - An Examination of its antecedents and its purposes. Political Science Quarterly, 76(2), 181-200.

Hall, M. J. B. (2002). Incentive compatibility and the optimal design of deposit protection schemes: An assessment of UK arrangements. Journal of Financial Regulation and Compliance, 10(2), 115-134.

Howarth, D., \& Quaglia, L. (2017). The difficult construction of a European Deposit Insurance Scheme: a step too far in Banking Union? Journal of Economic Policy Reform, 20, published online Dec 1, 2017, https://doi.org/10.1080/17487870.2017.1402682.

IADI - International Association of Deposit Insurers (2009). The Effect of DIS on Banking Sector Development: The Example of Kazakhstan, Russia, and Ukraine. Research Paper, Eurasia Regional Committee, Basel: International Association of Deposit Insurers.

Kravchuk, H., \& Vilkhovyk, O. (2014). Prospects for the development of deposit insurance in context changes in the level of moral hazard. Visnyle of the Chernibiv National Technological University, 1(72), 231-236.

Laeven, L. (2004). The Political Economy of Deposit Insurance. Policy Research Working Paper; No.3247. Washington, D.C.: The World Bank.

Laeven, L. (2014). Deposit Insurance in the European Union. In C. Enoch, L. Everaert, T. Tressel, \& J. Zhou (Eds.), From Fragmentation to Financial Integration in Europe (pp. 279-293). Washington, D.C.: International Monetary Fund.

Lakstutiene, A., Barkauskaite, A., \& Witkowska, J. (2018). The importance of systemic risk assessment in a risk-based common European Union deposit insurance system: case of Lithuania. Economic Research - Ekonomska Istrą̌ivanja, 31(1), 73-86.

Lee, S.-C., Lin, C.-T., \& Tsai, M.-S. (2015). The pricing of deposit insurance in the presence of systematic risk. Journal of Banking \& Finance, 51, 1-11.

Lee, S.-J., Mayers, D., \& Smith, C. W. Jr. (1997). Guaranty funds and risk-taking - Evidence from the insurance industry. Journal of Financial Economics, 44(1), 3-24. 
Masciandaro, D. (2007) Divide et Impera: Financial supervision unification and the central bank fragmentation effect. European Journal of Political Economy, 32(2), 285-315.

Niinimäki, J.-P. (2002). Bank panics in transition economies. BOFIT Discussion Papers 2/2002. Helsinki: Bank of Finland, Institute for Economies in Transition (BOFIT).

Ngalawa, H., Tchana, F. T., \& Viegi, N. (2016). Banking instability and deposit insurance: The role of moral hazard. Journal of Applied Economics, $19(2), 323-350$.

Ngo, P. T. H., Puente, D., \& Virani, Z. (2016). The Role of Deposit Insurance in Liquidity Risk Management: Evidence from Systematic Banking Crises. Melbourne: Melbourne Business School, 2016 Financial Institutions, Regulation \& Corporate Governance (FIRCG) Conference.

Nodia, G., Cenușă, D., \& Minakov, M. (2017). Democracy and its Deficits: The path towards becoming European - style democracies in Georgia, Moldova and Ukraine. CEPS Working Document, No. 2017/12. Brussels: Centre for European Policy Studies.

On the System of Guaranteeing Natural Person Deposits (2012). Legislation of Ukraine, Doc 4452-VI, $1^{\text {st }}$ version Feb 23, 2012. Accessed June 1, 2017. http://zakon2.rada.gov.ua/laws/show/4452-17.

Palubinskas, G. T., \& Stough, R. R. (1999). Common Causes of Bank Failures in Post-Communist Countries. Working Paper, The Institute of Public Policy, George Mason University, http:/ / citeseerx.ist.psu.edu/viewdoc/download?doi=10.1.1.195.783\&rep=rep1\&type=pdf.

Pauly, M. V. (1974). Overinsurance and Public Provision of Insurance: The Roles or Moral Hazard and Adverse Selection. Quarterly Journal of Economics, 88(1), 42-64.

Payne, J. (2015). The Reform of Deposit Guarantee Schemes in Europe. European Company and Financial Law Review, 12(4), 539-562.

Poissonnier, A. (2017). The Baltics: Three Countries, One Economy? European Economy Economic Briefs 024, Brussels: European Commission.

Ronn, E. I., \& Verma, A. K. (1986). Pricing Risk-Adjusted Deposit Insurance: An Option-Based Model. The Journal of Finance, 41(4), 871-895.

Savchenko, T. G. (2011). Структура механізму впливу банківської системи на рівноважні стани у економіці. Economy and Region, 31(4), 53-59.

Savchenko, T. G., \& Kovács, L. (2017). Trust in the banking sector: EU experience and evidence from Ukraine. Financial Markets, Institutions and Risks, 1(1), 29-42.

Schoenmaker, D., \& Gros, D. (2012). A European deposit insurance and resolution fund. Working Paper, No. 364, Amsterdam: Duisenberg School of Finance.

Schönfelder, B. (2012). Vom Spätsożialismus zur Privatrechtsordnung, eine Untersuchung über die Interdependen₹ zwischen Recht und Wirtschaft am Beispiel von Gläubigerschutz und Kredit. Berlin: Berliner Wissenschaftsverlag.

Stiglitz, J. E. (1975). Some Aspects of the Pure Theory of Corporate Finance: Bankruptcies and Takeovers. Bell Journal of Economics, 3(3), 458-482.

Straßberger, M., \& Sysoyeva, L. (2016). Die aktuellen Entwicklungen der Bankenaufsicht im Lichte der Stabilität des Finanzsystems. Wirtschaftsdienst, 96(7), 486-491.

Stuchlik, A. (2016). European Deposit Insurance Scheme. Completing the Banking Union, EU legislation in progress. European Parliamentary Research Service. Brussels: European Parliament.

Talley, S. H. \& Mas, I. (1980). Deposit Insurance in Developing Countries. World Bank Policy Research and External Affairs Working Paper, WPS 548. Washington, D.C.: The World Bank.

Thomann, E., \& Zhelyazkova, A. (2017). Moving beyond (non-)compliance: the customization of European Union policies in 27 countries. Journal of European Public Policy, 24(9), 1269-1288.

Vasilyeva, T. A., \& Lunyakov O. V. (2013). Financial cycles and financial imbalances in the economy. Економіка і регіон, 40(3), 124-130. 